\title{
Debit Gas in Well as a Comprehensive Indicator of Gas Permeability of the Coal Seam
}

\author{
Shevchenko Leonid A. \\ T. F. Gorbachev Kuzbass State Technical University, \\ Kemerovo, Russian Federation \\ aotp2012@yandex.ru
}

\begin{abstract}
The possibility of determining the coefficient of permeability of coal seams on debit degasification wells with different orientation with respect to the main fracture systems based on the Darcy law for a fractured porous media. The technique of calculating the permeability coefficient of coal seams in their natural state on the basis of measured values of gas emission from the inner surface of the wells. The concept of permeability tensor and its relationship with the system of cracks in the coal array. The comparative evaluation of gas permeability coefficients calculated for certain strata of Kuzbass in different directions vectors of gas flows. It is recommended to use the proposed methodology for the design of degassing prepared for extraction of coal seams in order to reduce the natural gas content to a predetermined level ensuring the safety of underground coal mining.
\end{abstract}

Keywords - coal seam wells, gas permeability, fracture system, filtration, methane.

\section{INTRODUCTION}

The current pace of extraction works in the coal mines of Russia and first of all in Kuzbass is impossible without radically addressing gas emission management within the excavation sites equipped with high-complex capable to provide coal production up to 3-to 4 million tons per year from a long wall face. In 2015, the production of coal in particular in Kuzbass totaled 215.2 million tons, which was a record for its history. However, this rate of coal production is impossible without solving the main problems in underground mining operations - the problem of the gas barrier of coal mines.

The only technically feasible means of addressing this problem is the degassing of coal seams before the beginning of their development, which is envisaged in the Federal Law "On state regulation in the field of extraction and use of coal, about the features of the social protection of employees of the coal industry organizations on 07.07.2010 [1], as well as in other normative acts of the Russian Federation [1].

Degassing is also mandatory when issuing licenses for the development of new coal deposits and operating mining enterprises developing coal seams with the gas content of more than $13 \mathrm{~m} 3 / \mathrm{t}$. In this regard, the requirements of mine air safety have significantly increased, and above all the quality of the preparation of the degassing of coal seams to the recess. The main element in this system are degassing wells giving the ability to extract methane from the reservoir to reduce its natural gas presence policy to the values that are set in Kuzbass at $8 \mathrm{~m} 3 / \mathrm{t}$. To solve this problem a detailed study is required of the interaction of the well and the coal array using experimental and theoretical methods of research and generalization of earlier results [2-14].

One of the indicators characterizing the ability of the coal seam to filter gas is permeability coefficient. In the laboratory the attempts to simulate the natural state of the array and the gas pressure involve many difficulties. On the other hand, the gas flow rate into the wellbore is directly dependent on the properties of the near-zone array in natural conditions and it can fully characterize the flow properties at any time. This provision could serve as a basis for the method of an approximate calculation of the gas permeability coefficient of the coal seam from the measured values of the flow rate in degasification wells at a certain time interval.

\section{MATERIALS AND METHODS}

Degassing in degasification wells since the start of drilling can be conditionally divided into two stages. The first stage degassing in the drilling period, the second phase - degassing after drilling and well connection to the vacuum pump. Assuming equal length of one series of wells and drilling speed, it can be assumed that all wells are drilled for the same period of time t0 (Fig.). As practice shows, the maximum gas flow rate of any well is observed at the end of drilling (point A1, A2, A3), when the gas recovery surface is completely formed in the well.

Given the heterogeneity of the coal seam along the dip and strike, different wells may have different characteristics as to the maximum production rate and the pace of its reduction over time. Based on the fact that the resulting curves are experimental and fully reflect the filtration properties of the reservoir, they can be used as a source of experimental data to solve a number of practical problems. It is necessary to know the value of natural gas pressure at the site of the formation and the natural gas content determined at the stage of geological exploration. The collection of empirical data can provide the basis for an approximate determination of the gas permeability of the coal seam in a particular direction of gas flow. Taking into account that the internal surface of the borehole is cylindrical, its area can be determined by the formula: 


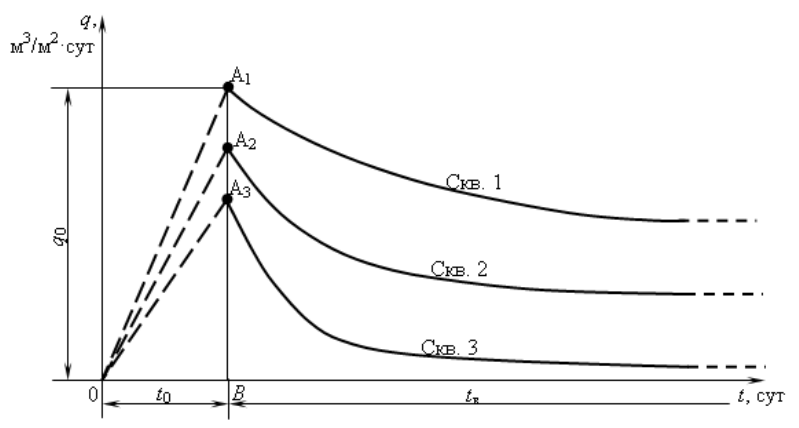

Fig. Typical curves of gas flow rate into the wells in the areas with different permeability of coal seams:

$\mathrm{t}_{0}$ - Drilling time, $\mathrm{t}_{\mathrm{v}}$ - time work under vacuum

$$
S=\pi d l_{w}
$$

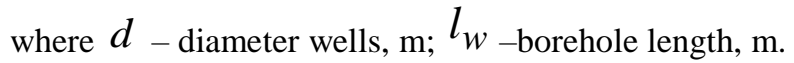

Given that the diameter of degassing wells varies, generally in the low range - $100-130 \mathrm{~mm}$, the expression (1) can be written as. Gassing occurs well in the entire area of its inner surface, which is formed during drilling. In this regard, to take into account that each borehole section will be included in the gas recovery process at different points in time, causing the intensity of the gas filter of the well length will be uneven, but this circumstance with a relatively small lengths wells $(150 \mathrm{~m})$ is not of a practical significance, since the drilling does not exceed one or one and a half shifts, but with long lengths (up to $1000 \mathrm{~m}$ ) of wells it is necessary to take this into account in the calculations.

As a benchmark for calculating the filtration rate of methane to the walls of the well layer should be used at the end of gassing, of borax, because it can be easily determined and depends on the filtration properties pla-hundred vector in the direction directed towards the axis of the borehole. In this case, the inner surface of the filtration rate of gas wells will be determined from the expression

$$
V=\frac{q_{0}}{86400 \cdot \pi \cdot d \cdot l_{\mathrm{W}}, \mathrm{M} / \mathrm{c}}
$$

where $q_{0}$ - measured total value of the gas flow rate at the time of the end of drilling, $\mathrm{m} 3 / \mathrm{m} 2 \cdot$ sut. Given that the actual speed of the coal seam methane with very small cracks and holes formation amounts to $0.06 \mathrm{~mm} / \mathrm{s}$, in addition, it changes little over time, it will not cause a significant error in the calculations. As follows from the law of Darcy main factors determining the rate of gas flow through fractured porous media are gas permeability coefficient of dynamic viscosity of methane at the temperature at this depth and pressure gradient on the contours of power and flow $\frac{d P}{d R}$, which is expressed by the formula

$$
V=-\frac{K}{\mu} \cdot \frac{d P}{d R}, \mathrm{~m} / \mathrm{cs}
$$

Omitting sign and expressing the factor, we get a view of the formula (2)

$$
K=\frac{\mu q_{O}}{86400 \pi d l_{\mathrm{W}} \operatorname{gradP}}, \mathrm{m}^{2}
$$

where $q_{0}$ - value of methane production rate from the well when drilling the end, $\mathrm{m} 3 / \mathrm{m} 2 \cdot$ sut.

After substitution of the numerical values of constants the formula (4) takes the form

$$
K=\frac{1,092 \cdot 10^{-5} \cdot q_{0} \cdot R_{i}}{2,712 \cdot 10^{5} d l_{w}\left(P_{0}-P_{1}\right)}
$$

where $R_{i}$ - the radius of influence of the well, which was formed by the end of drilling, $\mathrm{m} ; P_{0}$ - the gas pressure in the reservoir, $\mathrm{Pa} ; P_{1}$ - pressure on the inner surface of the well, $\mathrm{Pa}$.

In the formula (5), of particular importance is the procedure for determining the gas pressure gradient in the zone of influence of the well as a factor that significantly affects the intensity of the methane filtering to its exposed surface, which is a loop flow. Since the gradient giving-ment is the ratio of the pressure difference in the array and the borehole wall, where the pressure can be taken equal to atmospheric pressure, the radius of influence of a well at the moment, then with increasing radius it will gradually decrease, causing a corre-, respectively, and a decrease in filtration rate of methane up to its termination. However, at the initial stage of the well when it is drilled, the influence radius is quite small and does not exceed $0.5 \mathrm{~m}$ at the time of drilling completion. For functions that characterize the development of the radius and effect borehole over time after the end of the drill, you must have the curve of the methane production rate during this period that requires a additional observation for 2and 3 months which is not included in the task of this article. However, the reduction of gas pressure gradient in time is inevitably accompanied by a decrease MSE-velocity gas filtration in the formation that in calculating the coefficient of permeability should give the same result. Calculations of gas permeability coefficients performed for some layers of Kuzbass on the above procedure are shown in the Table 1. 
TABLE 1. Calculated On The Well Flow Rate Values Of The Coefficients Of Coal Seams Permeability In Kuzbass At Different Orientations Of The Well In The Reservoir Plane

\begin{tabular}{|l|c|c|c|c|}
\hline Plast & $\begin{array}{l}\text { The flow rate of the } \\
\text { well at the end of } \\
\text { drilling, } \mathrm{m} 3 / \mathrm{m} 2 \cdot \text { sut }\end{array}$ & $\begin{array}{l}\text { Natural gas } \\
\text { pressure, MPa }\end{array}$ & $\begin{array}{l}\text { The radius of influence } \\
\text { of the well at the end of } \\
\text { drilling, } \mathrm{m}\end{array}$ & $\begin{array}{l}\text { permeability } \\
\text { coefficient, } \mathrm{m} 2\end{array}$ \\
\hline \multicolumn{5}{|l|}{ The wells in the formation plane (plane parallel to the filtration) } \\
\hline Powerful & 6.60 & 1.4 & 0.5 & $3.2 \cdot 10^{-16}$ \\
-"- & 8.95 & 1.2 & 0.5 & $5.1 \cdot 10^{-16}$ \\
Lutuginsky & 6.30 & 1.0 & 0.5 & $4.4 \cdot 10^{-16}$ \\
\hline Wells oriented across the strike of the formation (radial filtering) & $4.7 \cdot 10^{-15}$ \\
\hline $\begin{array}{l}\text { Powerful } \\
\text { Burnt }\end{array}$ & 96.83 & 1.4 & 0.5 & $4.5 \cdot 10^{-15}$ \\
\hline
\end{tabular}

\section{RESULTS}

As seen from the Table, the values of permeability coefficients for various wells differ by an order or more of the same formation according to the wells and the orientation in space of unsealed cracks. The maximum value of gas permeability coefficients is for holes oriented perpendicular to the plane of the reservoir, and the minimum - well reservoir. There are also other gas flow directions in the coal array, but they can all be characterized by different values of permeability coefficients generated at the combined filtering modes. The results obtained allow to reconstruct the shape and space volume of the solids, which are formed within the filtration of gas flows under the influence of differential pressure created in the borehole direction of the velocity vector.

Wells oriented across the strike of the formation forming the filtering body in the form of a circular cylinder height equal to the capacity of the reservoir, and the reservoir of the well - in the form of an ellipsoid with axes equal permeability coefficients, respectively, bedding and perpendicular to it. In cases where a well is drilled in a powerful formation of a gentle fall of lying to the hanging wall, the volume of filtration is an oblique circular cylinder of radius equal to the coefficients of permeability in the reservoir plane. Thus, on the basis of the above we can conclude that the permeability of the coal seam in the direction specification requires methane filtering vector that is caused by the structure of the genesis and sedimentary deposits with fracture anisotropy. In addition to this we must add that the filtration properties of coal seams are reduced to the depth of development due to increased overburden pressure and temperature of the country rocks, which, in turn, increases the viscosity of methane.

Meanwhile, in the scientific literature, there is no clear distinction concerning the permeability of coal fracture system, as, indeed, there is no methodology for determining the permeability of the formation rate on the experimental data of wells, reliable enough for practical use. Laboratory methods for determining the filtering ability of different grades of coal, previously published, although they are more stringent, involve the use of coal samples in isolation from the natural array, which in itself introduces an error in the results obtained [4]. The experiments were carried out in field conditions by discharge pressure in the well, in parallel experimental measurements and gas filtration rate in the inter-well space, are time-consuming and in practice, the mines are not applicable. Nevertheless, we must recognize that the values of permeability coefficients obtained by specially designed experiments and the data of degasification wells, give numbers of the same order.

No less important in assessing the permeability of the coal seams is also taking into account their state of stress, which may vary as a result of overworking or by other influences that could cause an increase in coal fracture and thus increase its permeability. The result of these influences can be natural partial degassing of the adjacent coal seams and, as a consequence, reducing their natural gas content, which is also important in the development of coal-bearing formations containing layers prone to rock bumps and sudden outbursts of coal and gas. A similar conclusion can be drawn regarding the development of powerful coal seams with the division into layers, where the recess of the first layer significantly contributes to the natural degassing temporarily increases the thickness and the wells located in it sharply increase their production rate. Given the wide variety of geological conditions of Kuzbass both in terms of thickness of coal seams and in terms of the angles of incidence and convergence of location, as well as development of depth, it should be considered as appropriate the formation of the bank of the experimental data for each mine and each reservoir which can then be used as reliable reference parameters for the design of degassing to ensure the accuracy of the calculations and the actual decrease in the gas danger of mines under high load on the working face and, as a consequence, the complete removal of restrictions on the gas factor. This approach is also 
recommended in the operating instructions for the degassing of coal mines (application number 18 Determination of the amount of captured methane) [15]. In addition, the proposed method of calculating the coefficient of permeability of coal seams can be used also in the implementation of the industrial extraction of methane from coal seams of abandoned mines, which is currently an important economic problem.

\section{CONCLUSIONS}

Based on the above, we can draw the following conclusions:

1. High rates of coal seams mining require different approaches to the study of solid state adjacent to the working face in terms of its gas-dynamic state and intensity of gas recovery.

2. The gas permeability of the coal seams is a complex indicator characterizing their flow properties and, consequently, the ability of gas recovery in the on-board to expose the surfaces, which are the degassing boreholes.

3. The measured filtration rate values to methane wells walls allow to calculate the coefficient of gas permeability of the coal seam for known values of gas pressure gradient in a radial direction from the borehole axis.

4. The proposed method for calculating the permeability constant of the coal seam can be used as initial values of the current parameters of the degassing systems without resorting to costly and labor-intensive special experiments in mines.

\section{REFERENCES}

[1] Federal'nyj zakon «O gosudarstvennom regulirovanii v oblasti dobychi $\mathrm{i}$ is-pol'zovanija uglja, ob osobennostjah social'noj zashhity rabotnikov organizacij ugol'noj promyshlennosti» ot 07.07.2010.

[2] Shevchenko L.A. Processy gazootdachi gazonosnogo massiva v dlinnye skvazhiny. Vestnik Kuzbasskogo gosudarstvennogo tekhnicheskogo universiteta. - \# 3-2014. - S. 51-55.

[3] Barenblatt G.I. Dvizhenie zhidkostej $\mathrm{m}$ gazov v prirodnyh plastah. M.: - Nedra. - 1984. - 211 s.

[4] Hodot V.V. Vnezapnye vybrosy uglja i gaza. - M.: Gosgortehizdat. 1961. $-362 \mathrm{~s}$.

[5] Tajlakov, O.V. Ocenka fil'tracionnyh svojstv ugol'nyh plastov / O.V. Tajlakov, A.I. Smyslov, E.A. Utkaev // Gazovaja promyshlennost'. - \# 672. M.: Izdatel'stvo «Gazojl press». - 2012. - S. 24-25.

[6] Zastrelov D.N. Utilization Prospects of Coalbed Methane in Kuzbass // Zastrelov D.N., Tailakov V.O., Efremenkov A.B. Applied Mechanics and Materials. - 2015. - Vol. 756. pp. 622-625.

[7] Tajlakov, O.V. Fizicheskoe modelirovanie fil'tracii fljuida v ugol'nom plaste dlja ocenki radiusa skin-jeffekta / O.V. Tajlakov, E.A. Utkaev, D.N. Zastrelov, A.I. Smyslov // Gornyj informacionno-analiticheskij bjulleten'. M.:- MGGU. - 2013. - vyp. \# 6. - S. 165-169.
[8] Polevshhikov, G.Ja. Opredelenie gazokineticheskih harakteristik ugol'nyh plastov / G.Ja. Polevshhikov, A.A. Rjabcev, V.P. Titov // Vestnik Nauchnogo centra po bezopasnosti rabot $\mathrm{V}$ ugol'noj promyshlennosti. - Kemerovo. - 2013. - \# 2. - S. 78-84.

[9] Polevshhikov, G.Ja. Chislennoe modelirovanie povedenija hrupkih anizotropnyh ma-terialov i konstrukcij iz nih pri dinamicheskih nagruzkah / A.V. Radchenko, G.Ja. Polevshhikov // Izvesti Altajskogo gosudarstvennogo universiteta. - 2014. - \# 1. - S. 114-117.

[10] Polevshhikov, G.Ja. Nelinejnye izmenenija metanoobil'nosti vysokoproizvodi-tel'nogo vyemochnogo uchastka / G.Ja. Polevshhikov, E.N. Kozyreva, M.V. Shinkevich // Bezopasnost' truda v promyshlennosti. - Moskva. - 2014. - \# 6. - S. 50-54.

[11] Shevchenko, L.A. Gazovydelenie iz otbitogo uglja pri intensivnoj otrabotke ugol'nyh plastov / L.A. Shevchenko, S.N. Livinskaja // Vestnik Kuzbasskogo gosudarstvennogo tekhnicheskogo universiteta. \# 1. - 2015. - S. 104-106.

[12] Tkachenko, D.A. Vlijanie dliny degazacionnyh skvazhin na strukturu ih debita / Vestnik Kuzbasskogo gosudarstvennogo tekhnicheskogo universiteta. - \# 2. - 2015. - S. 78-81.

[13] Shevchenko, L.A. K voprosu o povyshenii tochnosti rascheta debita metana iz dega-zacionnyh skvazhin / Sovremennye koncepcii nauchnyh issledovanij / sb. nauchnyh trudov. Evrazijskij sojuz uchenyh. - Chast' 1. - M.: - 2015. - S. 160-163.

[14] Shevchenko, L.A. O nekotoryh polozhenijah Instrukcii po degazacii ugol'nyh shaht / Bezopasnost' truda v promyshlennosti. - \# 5. - 2015. S. 78-80.

[15] Instrukcija po degazacii ugol'nyh shaht. - M.: ZAO NTC issledovanij problem promyshlennoj bezopasnosti. - 2014. - $250 \mathrm{~s}$.

[16] Tailakov V.O. Physical Modeling of Fluid Flow in the Near-Wellbore Formation Zone jn the Basis of Equivalent Materials/ // Tailakov V.O., Utkaev E.A., Zastrelov D.N., Sokolov D.N. - Applied Mechanics and Materials. - 2015. - Vol. 770. pp. 349-353.

[17] Tailakov V.O., Makeev M.P.Development of method of rapid analysis of particle size distribution of the coal charge based on digital image processing // Tailakov V.O., Makeev M.P., Kormin A.N., Smyslov A.I. - Applied Mechanics and Materials. - 2015. - Vol. 770. pp. 355-360. 